a mineral in a state of fusion below its ordinary melting-point may allow of the previous crystallisation of another, which cannot sustain such conditions, and thus the normal order of crystallisation may be reversed. This fact is used to explain the crystallisation of augite before the felspar in basic rocks, which, in normal circumstances, so frequently show ophitic structure.

All through the book the influence of personal experiment remains manifest, and we must not complain if the genesis of the sedimentary rocks is treated in a somewhat rapid fashion. Flints thus receive far less than their due (p. 232), considering how much they have been discussed. Guppy's observations on silicified corals in the Fiji Islands raise, for instance, new questions in themselves. But references to recent work, such as Linck's on the separation of calcium carbonate from sea-water, will lead the reader forward; and we turn back contentedly from these scantier pages to the fine account of the problems of contact-metamorphism, and thank the author again and again for his clear and stimulating treatise.

As is natural in so wide a field, we miss mention of some memorable work, such as that of Harker on mixed rocks in the Inner Hebrides; on the other hand, we hail with delight the name of MacGregory (p. 3I), who appears to be Prof. J. W. Gregory in the glory of a Scottish title.

Grenvilie A. J. Cole.

\section{STRUCTURES AND MATERIALS.}

Theory of Structures and Strength of Materials. By Prof. Henry T. Bovey. Fourth edition. Pp. xiii + 968. (New York: John Wiley and Sons; London : Chapman and Hall, i905.) Price il. i is, 6d. net.

THIS well-known text-book has been largely re1 written and enlarged for the present fourth edition. In the preface Prof. Bovey states that a number of fresh examples, mostly drawn from actual practice, have been added to the various chapters, and that all tables of strengths, elasticities, and weights of materials have been brought up to date.

In chap. i. a description of Bow's method of notat:on is given, and the author has now adopted this system throughout the book when dealing with stresses developed in framed structures. The treatment of the three-hinged braced arch for station roofs and for sheds of wide span is a new piece of work in this chapter. In chap. ii. there is a new series of paragraphs dealing with the graphical determination of the maximum bending moment at any point of an arbitrarily loaded girder, and several examples illustrating the author's methods are worked out in full. Chap. iii. of the older editions has wisely been broken up into two chapters, one (chap. iii.) dealing with momentum, energy, and balancing, and the other (chap. iv.) with stress. strain, and elasticity. In the older editions this chapter was a very difficult one for the student to follow, and the author, in rewriting and dividing it, has brought the various steps of the work into their true relation one with the other. The whole of the material in chap. $x$. of NO. I 9 I 5 , VOL. 74] the older editions, which dealt with thick-walled, hollow cylinders, has now been incorporated into chap. v., which treats of the more difficult work on stress and strain, and undoubtedly it follows more naturally in this position after the discussion of the general equations of stress.

In chap. vii., in dealing with the relation of the neutral plane to the stress at any point in a beam, Prof. Bovey has incorporated the results of his own experimental work, which was carried out with the view of determining within the limits of elasticity the changes of fibre length at different depths of a beam when loaded transversely. In this chapter there are also additional paragraphs dealing with the design of reinforced concrete beams, the position of the neutral axis, and the strength of such beams; additional graphical methods are given for determining the slope and deflection in loaded beams, and in connection with the theory of continuous girders fresh matter has been introduced.

In chap. viii., which deals with the theory and the bending of struts, the results of the most recent experiments have been incorporated, and, as the chapter has been rearranged, it is now much more useful to engineers engaged in the difficult problem of strut design. In chap. ix. the stresses in non-circular shafts are discussed, and there is also much new matter in the paragraphs on the efficiency of shafting and the whirling of shafting, and open coil springs are dealt with, as well as the ordinary helical springs. Chap. x., which is devoted to bridges, has been entirely rewritten and greatly improved. Graphical methods are used throughout for the determination of stresses in the piers, and the most recent types of bridges are discussed and explained. Excellent tables are given of the loads upon, and the weights of, bridges, and several examples of fairly large bridges are worked out in complete detail. This chapter is now a most valuable one for those who are concerned with the design of bridges of all classes, and the examples have been made thoroughly practical. We have no hesitation in saying that Prof. Bovey in thus practically rewriting his book has considerably improved its value both to the engineering student and to the civil engineer engaged in the design of all classes of structures in steel and iron.

T. H. B.

\section{RATIONAL DAIRYING.}

Dairy Chemistry. By Harry Snyder. Pp. $\mathrm{x}+\mathrm{rgo.}$ (London: Macmillan and Co., Ltd.; New York: The Macmillan Co., Igo6.) Price 4s. $6 d$. net.

DROF. SNYDER'S work as agricultural chemist in the University of Minnesota is well known. This State, with a population less than that of Kent and Essex, possesses a University Agricultural Department in which are 800 students most of whom are attending a three years' course. The majority are students who during the summer months have to work for a living, and at the close of their academic training return to rural employment. Thus Min- 